\title{
An Archaeological Test Excavation at John James Park City of San Antonio, Texas
}

Susanna R. Katz

Follow this and additional works at: https://scholarworks.sfasu.edu/ita

Part of the American Material Culture Commons, Archaeological Anthropology Commons, Environmental Studies Commons, Other American Studies Commons, Other Arts and Humanities Commons, Other History of Art, Architecture, and Archaeology Commons, and the United States History Commons

Tell us how this article helped you.

This Article is brought to you for free and open access by the Center for Regional Heritage Research at SFA ScholarWorks. It has been accepted for inclusion in Index of Texas Archaeology: Open Access Gray Literature from the Lone Star State by an authorized editor of SFA ScholarWorks. For more information, please contact cdsscholarworks@sfasu.edu. 


\section{An Archaeological Test Excavation at John James Park City of San Antonio, Texas}

\section{Creative Commons License}

\section{(c) (1) (8)}

This work is licensed under a Creative Commons Attribution-NonCommercial 4.0 International License 


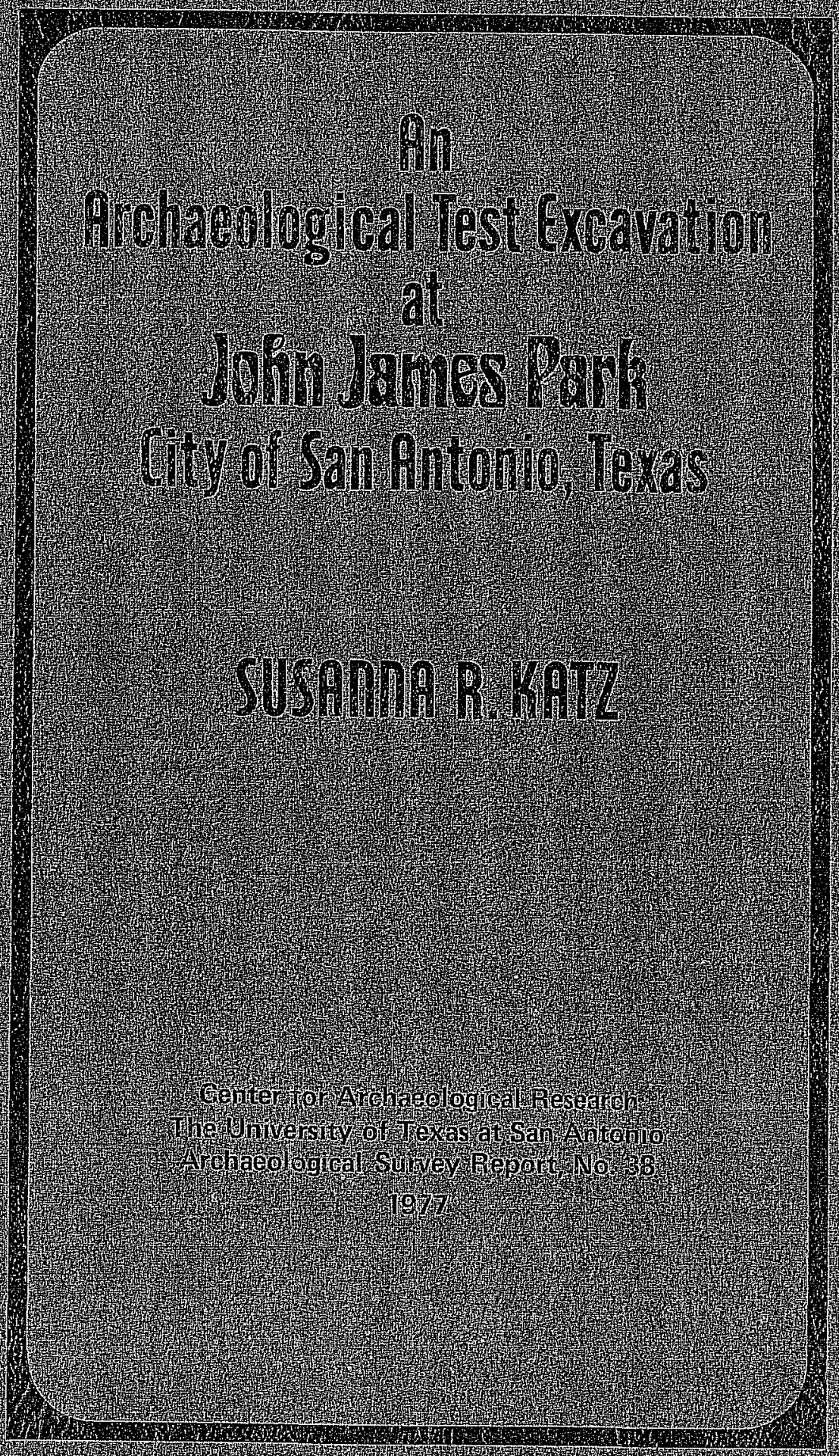

1) 140

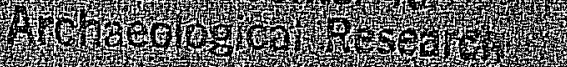




\section{AN ARCHAEOLOGICAL TEST EXCAVATION AT}

JOHN JAMES PARK, CITY OF SAN ANTONIO, TEXAS

Susanna R. Katz

Center for Archaeological Research

The University of Texas at San Antonio

Archaeological Survey Report, No. 38

1977 
Purpose...................... 1

Description of Site ............ 1

Testing Procedures ............ 2

Summary .................. . . 11

Recommendation ............. 12

Acknowledgments ................ 13

References cited ............ 13

\section{LIST OF FIGURES AND TABLES}

Figure

Page

1. John James Park............ . . 4

2. Site 41 BX $305 \ldots \ldots . . . . . . . . .7$

3. Selected Artifacts from 41 BX 305 ,

John James Park ........... 10

Table

1. Comparisons of Excavation Strategies ..... 3 


\section{PURPOSE}

An archaeological testing program at John James Park in the northeastern portion of San Antonio, Texas, was conducted for a two week period during the early summer of 1977. The research was funded by the City of San Antonio, Department of Parks and Recreation, under a contract with the Center for Archaeological Research of the University of Texas at San Antonio. Dr. Thomas R. Hester served as Principal Investigator.

Acting upon recommendations resulting from a surface survey (Phase I) of the Park (Frkuska et al. 1977), this testing phase (Phase II) carried out two objectives: establishment of precise spatial and chronological boundaries of the site, and evaluation of the eligibility of the site for listing in the National Register of Historic Places. The latter required the excavation procedures described below.

\section{DESCRIPTION OF SITE}

Site 41 BX 305 is located on the second major terrace above Salado Creek in John James Park. The Park, now in the planning and development stages, extends from Rittiman Road on the north to winans Road on the south. Artifacts were scattered on the west bank, paralleling the creek for almost the entire length of the Park. The area of least disturbance and most intensive artifact concentration, however, is situated within and adjacent to the 670foot closed contour in the northeastern section of the Park. It is within this area that test excavations were conducted (Fig. 1).

The Frkuska et al. (1977) assessment report divides the Park into three zones: Zone 1, a dump and fill area; Zone 2, the area of Site 41 BX 305; and Zone 3, an area of natural chert resources. The map (Frkuska et al. 1977:Fig. 1) is somewhat misleading, in that all of the area within the 670-foot contour is part of Zone 3 .

A11 zones were revisited and evaluated for excavation potential. Zone 1, the dump, was deemed too disturbed to warrant any testing. There was no archaeological material on the surface, and this area is probably too far from the creek to have been the scene of any but the most minimal prehistoric activity. There is always the possibility of subsurface material here, but it is highly unlikely.

Zone 2 is composed of two rather distinct areas. The upper (northern) portion is a broad flat terrace in the vicinity of the 670-foot contour; and the lower (southern) portion is a knoll and gully area which is restricted to the east side of the dirt road. The upper portion has good surface indications of archaeological material, and a testing plan was developed for it. The lower area is subject to flooding, dumping and disturbance by motorcycling. Although artifacts can be recovered from the sumface of the knolls, there is not enough of the original ground surface remaining to warrant further investigation of this area. 
Zone 3, the chert resource area, also showed considerable surface disturbance, in this case by pipeline construction, land clearing and dumping activities.

The chert resource is in cobble form and may have furnished some of the raw material for stone tool manufacture by the prehistoric peoples camped nearby. However, few of the cobbles showed signs of having been utilized, and there was no evidence of quarry activities or core reduction detritus on the surface. Because of the lack of signs of use of the resource, no excavation was considered necessary in Zone 3 .

\section{TESTING PROCEDURES}

The differences between a test and a full-scale excavation should be made clear, as they pertain to work done at John James Park. Table 1 reinforces the basic premise of test excavation: dig as little as possible for the greatest amount of information possible.

A test excavation is not a "miniaturized" version of a full-scale project. Rather, it is generally used as a preliminary method, especially of evaluation, when time and funds are limited. Test programs thus differ in procedures and goals from full-scale projects. While the test scope is more limited and its methods somewhat less rigorous than those used in a full-scale excavation, it is often a precursor to larger excavations.

Given that one focus of a testing program is to determine the areas of concentration within a site and the boundaries beyond which the site ceases to yield artifactual material, the discussion that follows is by necessity one of comparisons; e.g., different quantities of artifacts, relative intensities of occupation. Goals of a more complete excavation, such as artifact patterning, site structure and other evidences of human behavior, cannot be thoroughly explored.

Four parallel lines were established in the northern portion of Zone 2, each oriented magnetically north to south. Lines $A$ and $D$ were placed at either end of the surface artifact concentration, and lines $B$ and $C$ were between them. One-meter squares were laid out along these lines, each unit $15 \mathrm{~m}$ from the other. Line $A$, in the most open area, had seven squares, $B$ and $C$ had three, and $D$ had two. The decrease in excavation units reflected a combination of decrease in visible surface artifacts, decrease in number of volunteer workers, and decrease in remaining time allotted to the project.

Certain excavation procedures were standard for these units. All excavated soll was screened through a 1/4-inch mesh, with one exception. A11 chert chips, flakes and chunks, and all shaped tools, charcoal, bone and mussel shell fragments were collected. A representative sample of burned rock and snail shells was saved from each level.

The excavation proceeded by $10 \mathrm{~cm}$ levels (with two exceptions in 1 ine $A$ where a single 15-cm level was used). All shaped tools which were recognized in situ were plotted as to their exact proventence within the unit; all other 
TABLE 1

Comparisons of Excavation Strategies

Excavation

Procedure

Areal Extent

Volume

Unit Size

Horizontal

Control

Vertical

Control

Recovery

Procedure

Temporally

Diagnostic

Artifacts

Ecofactual

Data

Concentration

of Artifacts
Test Excavation

Extensive

Limited

Shovel Test or

Probe (minimum)

$1 \times 1$ Square (maximum)

Random

No Levels (shovel test) or Large Artificial Levels. Obvious Stratigraphic Levels
Ful1-Scale Excavation

More Limited

More Extensive

$1 \times 1$ Square (minimum)

Grid System

Smail Artificial Levels or Natural Stratigraphic Levels
Important

Less Important

Important
Less Important

Important

Less Important 
This page has been

redacted because it

contains restricted

information. 
artifacts were recorded by $10-\mathrm{cm}$ level. These materials were brought back to the laboratory at UTSA, where they were washed, labeled, sorted and cataloged. They are permanently stored at the laboratory, available for further research or display.

Line A

Line $A$ is situated .2 mile southeast of the intersection of Rittiman Road with the unimproved road that parallels the west side of Salado Creek. The Tine extends across a broad, open clearing, the first such clearing encountered as one proceeds southeast along the road. The ground surface here is nearly flat, except for a series of low, straight, seemingly artificial ridges that run both north-south and east-west in the clearing. These ridges are probably deposits from ground clearing operations conducted at some time in the past when the property was owned by Fort Sam Houston.

A line control point was established on the north edge of the dirt road, and seven tests units were initially laid out: A-1 nearest the creek bank, A-2 south across the unimproved road, and $A-3$ through $A-7$ continuing across the clearing. A $15 \mathrm{~m}$ east deviation occurred in the 1 ine at $A-5$ resulting from a small group of trees that had to be avoided. Unit A-8 was later added as a shovel test.

Units A-1 through A-4 were dug to a sterile gravel layer, which ocurred at depths ranging from 15 to $25 \mathrm{~cm}$. Units $A-5, A-6$ and $A-7$ were dug to sterile soil, about $15 \mathrm{~cm}$ below the surface. In these squares, the dark clay loam graded into a sandier, lighter clay before reaching the gravel; in A-1 through A-4, the dark soil rested directly on the gravel.

The layer of cultural material had a mixture of both prehistoric and modern artifacts. Prehistoric artifacts from these squares included chert flakes, chips and chunks. No shaped tools, no features and very little burned rock were present. The modern objects included metal wire, glass fragments, round-headed nails and shotgun shells. The artifact yield, in comparison with other areas in the site, was low.

Line B

Line $B$ was established $100.3 \mathrm{~m}$ southeast of Line $A$. Three squares were plotted: B- 1 nearest the creek, B-2 $15 \mathrm{~m}$ south and across the dirt road, and B-3 $15 \mathrm{~m}$ further south (Fig. 1). The line is in a small clearing at a slightly lower elevation than Line $A$ and is approximately midway through the area of surface archaeological indications. There does not appear to have been as much surface disturbance as was noted at Line A, since the "ridges" of topsoil were not present here.

Unit B-1 was dug until completely devoid of cultural material, this occurring in a gravel layer at a depth of $90 \mathrm{~cm}$ below ground surface. In this unit we obtained a much better stratigraphic sequence than was possible from Line $A$.

The first $50 \mathrm{~cm}$ of soil (Zone I) was a dark brown clay loam which gradually became lighter and more sandy. Zone II $(60-70 \mathrm{~cm})$ is a layer of gravel in a 
red sandy matrix. Stream cobbles are also present in this zone. Zone III $(70-90 \mathrm{~cm})$ is a red sandy clay with small pebbles distributed throughout. This level continues to a greater depth, but contains no further evidence of archaeological material (Fig. 2,a). It should be mentioned that the red gravel zone (II) does not resemble the fine red-yellow colluvial gravels noted at the St. Mary's Hall site (Hester 1975; and 1977 excavations) or at the Granberg site (Schuetz 1966:6); the gravels at 41 BX 305 are larger and more angular.

The first good indications of an unmixed, undisturbed cultural layer also appeared in this unit. The first $20 \mathrm{~cm}$ were mixed; that is, both modern and prehistoric material occurred in the levels. Below $20 \mathrm{~cm}$, however, no modern material was present, and the artifacts were lying horizontally, suggesting an undisturbed deposit. The amount of chert flakes, chips and shaped artifacts increased with each level until a depth of $40 \mathrm{~cm}$; below this depth, a decrease occurred. By the $80-90 \mathrm{~cm}$ level, only one chert flake was found in the entire unit. The bulk of artifactual material was thus contained with in the $20-50 \mathrm{~cm}$ levels.

Unit B-2 was excavated to a depth of $60 \mathrm{~cm}$. The upper levels of the untt were mixed, below $20 \mathrm{~cm}$, the amount of material increased and at $40 \mathrm{~cm}, a$ concentration of burned 1 imestone rock was uncovered. This concentration, designated Feature 1 , is heaviest in the southern half of the square; it probably continues further to the south, but time was not available to fully explore it. There were scattered bits of charcoal and a considerable number of chert flakes in association with it, as well as a biface fragment and an Almagre point. This association of a temporally diagnostic artifact with the feature suggests the placement of the feature within the Middle Archatc.

The nature of Feature 1 is not clear. There was no preparation of the ground surface below it, nor any hardening or discoloration of the soll to indicate the in-place burning one would expect of a hearth. The fact that very little charcoal was found also makes this interpretation somewhat questionable. Another possibility is that of a burned rock midden deposit. The concentration, large amount or chert detritus and lack of charcoal argue for this explanation. On the negative side, there is only a single layer of rock and most burned rock middens have several layers of stone. If this is the case, then it would be the peripheral portion of the feature that was uncovered. Without more information, however, it is impossible to state which interpretation is the correct one.

Unit B-3 had very little cultural material (less than one-fifth of the amount recovered from Unit B-2) and the unit was virtually sterile at a depth of only $40 \mathrm{~cm}$. No diagnostic artifacts were recovered from this square.

\section{Line $\mathrm{C}$}

This line is situated $36.5 \mathrm{~m}$ southeast of Line $B$; three excavation units were plotted on it in the same spatial relationships as those in Line $B$. 


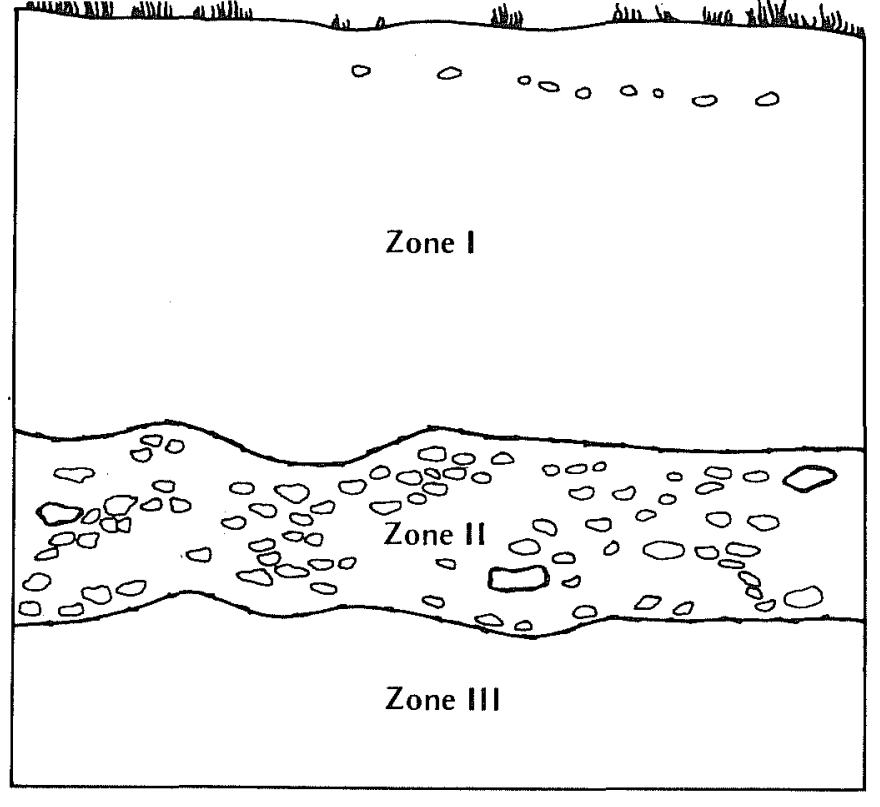

EAST WALL
Zone 1 - Dark brown clay loam grading lighter toward grapel layer

Zone II - Heavy, reddish sandy gravel around stream cobbles Zone III - Reddish sandy clay with some

a

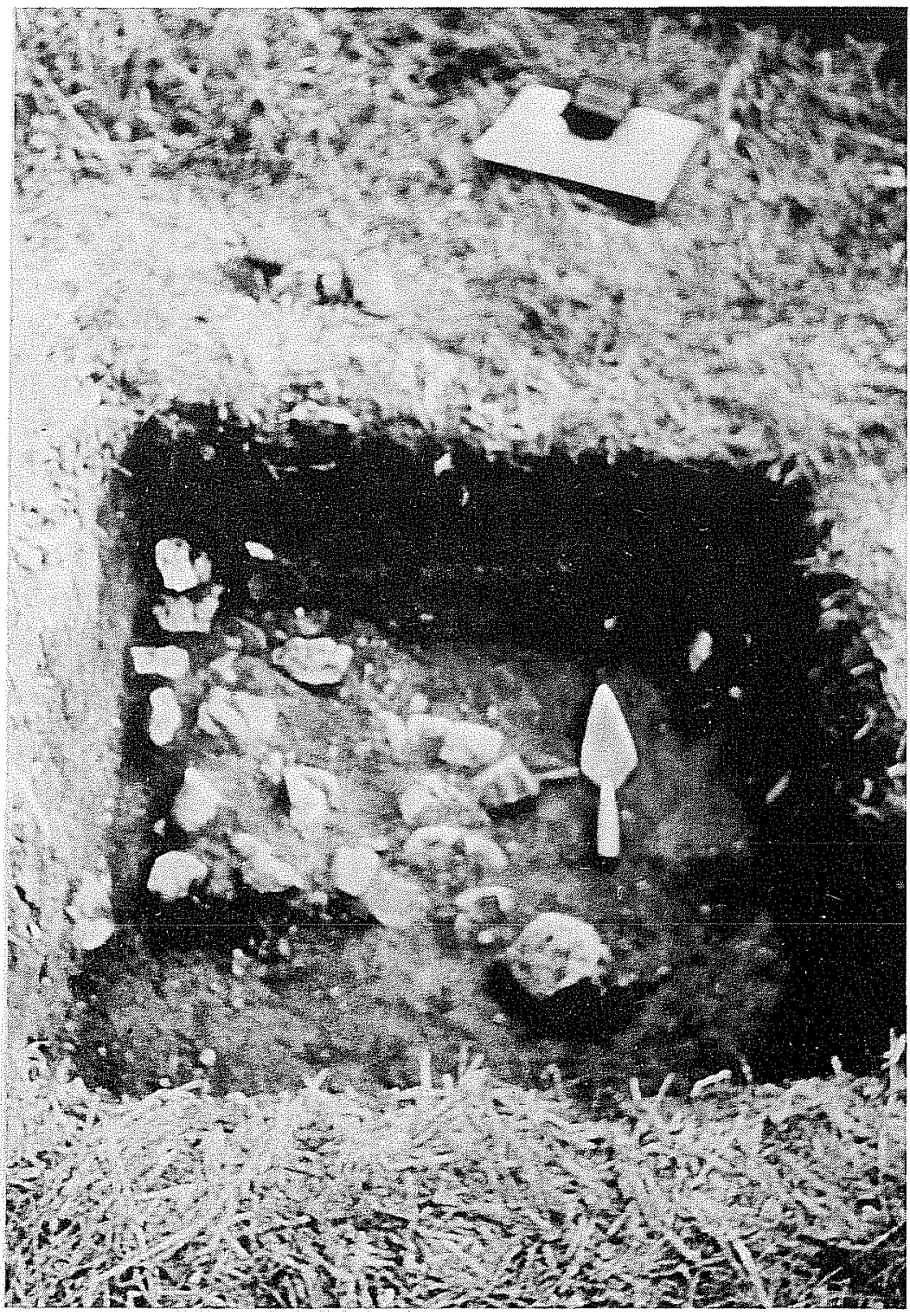

b

Figure 2. Site 41 BX 305. a, East profile, Unit B-1; Feature 1. 
The C-line squares had less material on the surface and corresponding ly less subsurface material than those in Line $\mathrm{B}$. Unit $\mathrm{C}-1$ was excavated to a depth of only $20 \mathrm{~cm}$, as the unit appeared to be sterile. Later, a shovel test was dug in the square to a depth of $50 \mathrm{~cm}$. Small charcoal flecks were noted in the soll, but no larger pleces of charcoal or burned rock were present. The gravel layer (Zone III in Fig. 2,a) appeared at $50 \mathrm{~cm}$.

Unit $\mathrm{C}-2$ duplicated the situation noted in $\mathrm{C}-1$; similarly, the uppermost levels were carefully excavated and the remainder was dug as a shovel test. The excavation of this unit was complicated by the presence of a very active anthil1. Although this disturbed the soil to some degree, it disturbed the unfortunate excavators even more.

Unit C-3 was once again a square with only a handful of chert flakes, but it was nonetheless excavated carefully and by $10-\mathrm{cm}$ Tevels. At $40 \mathrm{~cm}$ a concentration of burned limestone was uncovered. This concentration, designated Feature 2, contained several layers of burned rock below which was apparently a carbonized log. Almost all of the stones seem to have been contained within the excavation unit and very little cultural material was found in association with it. The compactness of the feature, the charcoal and the lack of artifacts within the feature itself suggest that this feature is a hearth. The feature is at the same depth as Feature 1, the burned rock concentration in Unit B-2. It was constructed directly on the ground surface; there was no indication of prior ground surface preparation and the stones did not appear to have been intentionally placed so as to form a lining for the hearth. As the charcoal was so plentiful and because both the feature and the deposit it is in appear to be undisturbed, a sample was collected and submitted to the Radiocarbon Laboratory at The University of Texas at Austin. The assay which results from the radiocarbon process will date not only the feature, but the entire occupation occurring at a similar depth below ground surface. It will supply a more precise date than the artifacts could provide.

Line $D$

Line $D$ was placed at the southern extent of surface artifact concentration, $44.1 \mathrm{~m}$ south of Line $\mathrm{C}$ and lower in elevation than any of the other lines. Two squares were plotted on the 1 ine, D-1 close to the creek and D-2 $15 \mathrm{~m}$ south and across the dirt road. A barrier of trees beyond the second unit precluded the addition of a third unit at the standard $15-\mathrm{m}$ interval.

This location had seemed the most promising for an occupation area because of the highest surface concentration of flakes, shaped tools and burned rock than was noted elsewhere. As at the other lines, the surface indications reflected the subsurface condition; more than twice the number of artifacts was recovered from $D-1$ and $D-2$ than from the other units.

D-1 was dug to sterile soil, $110 \mathrm{~cm}$ below the surface. It is interesting that the red sandy zone (Zone III, Fig. 2,a) was not reached in this unit. Rather, the gravel layer seems to extend to a greater depth in this part of the site. 
The upper $20 \mathrm{~cm}$ of $\mathrm{D}-1$ repeated the now familiar situation, in that there was a mixing of contemporary and prehistoric artifacts. No historic material was present below the $20 \mathrm{~cm}$ level. The bulk of archaeological material was contained within the $20-50 \mathrm{~cm}$ levels. An $80 \%$ drop in artifacts occurred from the 50-60 cm level and very few were found below that; the sharp drop in numbers occurred in conjunction with the appearance of the gravel layer. Several of the flakes from the $60-\mathrm{cm}$ level were heavily patinated and may or may not have been culturally produced.

Several diagnostic artifacts and other shaped tools were recovered from this unit, including two Pedernales points ( $F i g .3, a, b)$, a crude triangular biface (Fig. 3,c) and several bifaces. The points can be assigned to the Middle Archaic, roughly dated at 2250-650 B.C. (Weir 1976:64).

D-2 was very similar to D-1, although it was only excavated to $60 \mathrm{~cm}$, terminating in the uppermost centimeters of the gravel layer. As experience had shown that very little would be present below this level, no further time was allocated for its excavation.

The first $20 \mathrm{~cm}$ of the unit were screened through a 1/8-inch mesh. So much material was present in the form of minute chipping shatter that the process of screening so finely soon became too cumbersome, and the remainder of the square was screened with the larger 1/4-inch mesh. It was encouraging to note that the only difference between the mesh sizes was the recovery of the smallest chipping shatter and broken fragments of snall shell in the 1/8-inch screen. As an additional check, two buckets of dirt from Unit D-1 were screened, one through the 1/8-inch mesh and one through the 1/4-inch. Once again, only the amount of small chipping shatter and broken snail shells increased with the smaller-meshed screen and no new material categories were recovered.

Shaped tools from this unit included an expanding stem from a projectile point (Marcos?) and several biface fragments. Burned rock was present at 50 $\mathrm{cm}$, although no definite concentration was noted; the presence of burned rock between 40 and $50 \mathrm{~cm}$ throughout the site was predictable. The completion of Unit D-2 marked the end of this part of the testing program.

Addressing the problem of the site's horizontal extent, a series of 11 shovel tests were dug. A shovel test, in our project, was simply a shovel hole dug without regard to stratigraphic levels and without screening of the backdirt. Shovel tests at 41 BX 305 were used only to determine how far south from the creek the site extends. The tests were dug south of all the 1 ines, and southeast of Line D (Fig. 1). They were dug to a depth of $50 \mathrm{~cm}$, the depth to which cultural materials might be expected to occur. Results of these tests showed that the site thins out the farther south it extends from the Salado Creek. No shovel test, however, was completely sterile, and it is felt that a light scattering of artifacts is present subsurface throughout the entire Park area. The major occupation area, however, has been demonstrated to be oriented toward the creek and contained within $100 \mathrm{~m}$ to the south of it. 


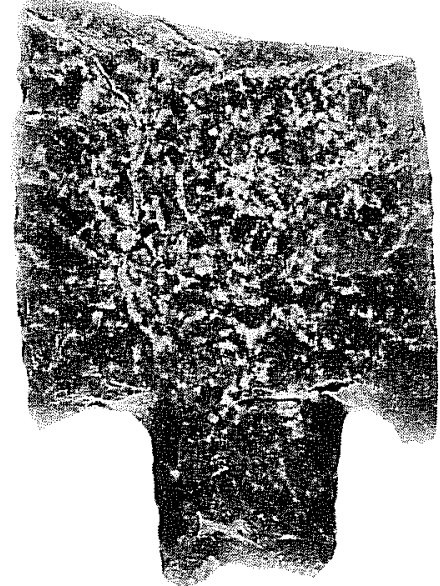

a

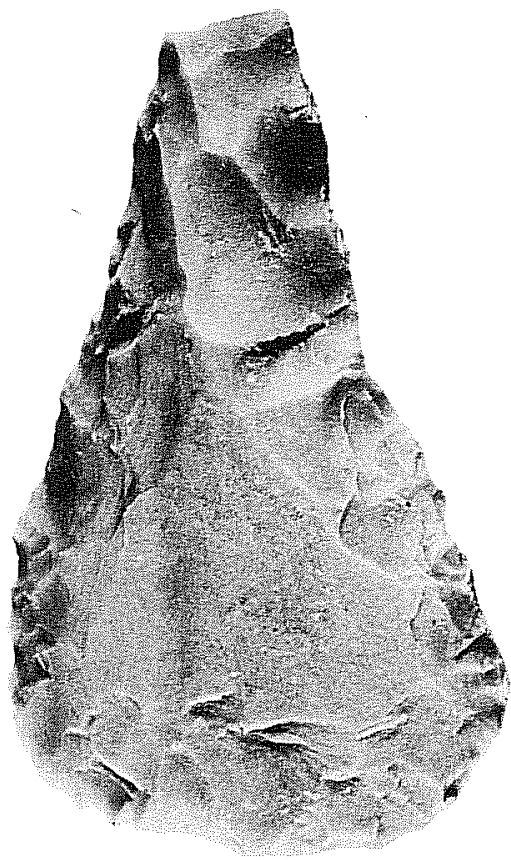

C

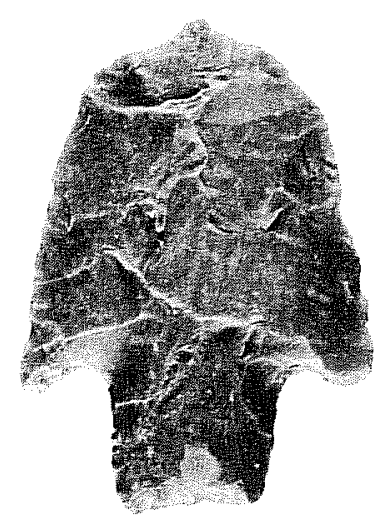

b

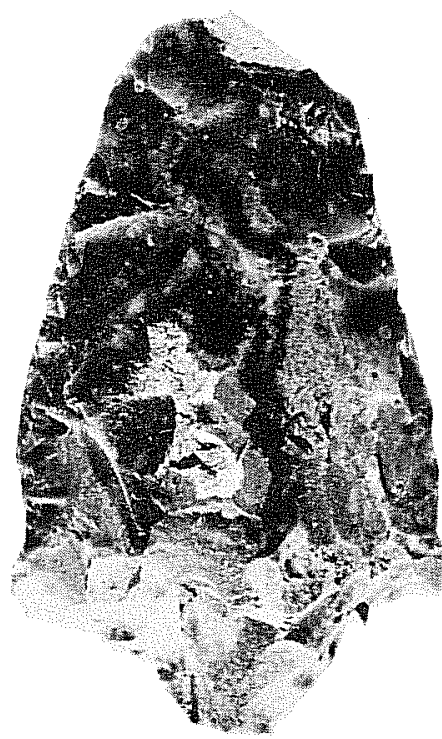

d

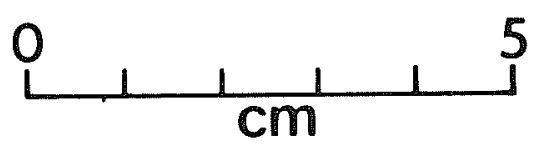

Figure 3. Selected Artifacts from 41 BX 305, John James Park. a, Pedernales point; $b$, Pedernales point; $c$, crude triangular biface; d, Almagre point. 
Another point of interest recognized from these shovel tests was that those nearest Lines $C$ and $D$ contained more artifacts than those near Lines $A$ and $B$. The tests nearest Line $C$ contained more artifacts than the line itself would have indicated; as was mentioned earlier, the $\mathrm{C}-3$ unit may have picked up the northern edge of an activity area.

The shovel tests near Line D contained several diagnostic artifacts, including a Montell point and a Castroville point, Late Archaic specimens dated to between 850 B.C. and A.D. 150 (Weir 1976:74).

Another technique employed at this time was the taking of soil cores from those units which had been excavated to sterile soil but which had not been excavated to the gravel layer. By this method, it was hoped that we could establish whether the gravel layer was at a uniform horizontal depth throughout the site. Two cores were taken from each of the units, one from the center of the square and one from the southwest corner. None of the cores contained any cultural material, and they all showed evidence of being at or immediately above the gravel layer by a depth of $60 \mathrm{~cm}$.

\section{SUMMARY}

With the information that had been gathered, questions of spatial boundaries of the site, its temporal placement and archaeological significance were addressed.

The site is situated adjacent to the Salado Creek and no more than $100 \mathrm{~m}$ south of its banks. The undisturbed, Middle Archaic deposit is located below the mixed zone $(20 \mathrm{~cm}$ below ground surface) and above the gravel layer (approximately $50-60 \mathrm{~cm}$ below ground surface).

The site dates to the Middle Archaic Period, roughly between 2050 B.C. to A.D. 150. It is a date from the charcoal sample submitted to the Radiocarbon Laboratory at The University of Texas at Austin will refine the chronological placement of this localized occupation.

The Middle Archaic was characterized by small groups of hunting and gathering populations; but not enough data has yet been collected in this region (or at the site) to say exactiy what faunal and floral resources were being exploited. The site appears to have been a campsite, and the large number of cutting and piercing tools that have been recovered from it suggests a connection with some sort of faunal processing activity.

The archaeological significance of each test area (Lines $A$ through D) was evaluated. Line $A$, an area of shallow and mixed deposits, was not considered worthy of further intensive investigation. Line $B, 100 \mathrm{~m}$ southeast, was considered more promising, but not necessarily important. Although there was a feature associated with this line, the amount of activity indicated by the artifacts was not significant. The $C$ line was almost devoid of artifacts, but contained one feature in Unit $\mathrm{C}-3$. It is possible that the site consists of a number of activity or camping areas, and that the space in which $\mathrm{C}-1$ and $C-2$ were plotted represents a void between these areas, while $C-3$ is 
possibly within an area. Line $D$ represents an intensive area of aboriginal utilization, based on the number of artifacts and burned rock that was recovered, even though no features were found.

\section{RECOMMENDATION}

Site 41 BX 305 in John James Park contains one area of undisturbed Middle Archaic deposit that is worthy of further investigation. The scientific, educational and interpretive value that would result from such investigation is considered significant and would warrant the nomination of the site to the National Register of Historic Places. The fact that the area is included in Park development plans is an important factor considered below in our recommendation.

The area in question is situated between Lines $C$ and $D$ and extends from the creek bank to no more than $100 \mathrm{~m}$ south of the bank (Fig. 1). The work here should consist of a controlled excavation with levels dug in arbitrary increments of not more than $5 \mathrm{~cm}$. It is highly probable that discrete occupation levels may be identified through this procedure. This method need not be used for the entire depth of the excavation units, however, but only between the 20-50 cm levels where the bulk of the occupation occurs. The area opened by excavation might be on the order of $36 \mathrm{~m}^{2}$.

It is recommended that the type of archaeological investigation described above be implemented before this portion of the park is developed or modified. An extension of the Phase II testing for an additional four weeks, with a crew of four persons, should be adequate for this recommended task. With the completion of this recommended work, it is believed that the archaeological resources of site 41 BX 305 (within the proposed John James Park) will have been sufficiently explored. Alternatively, it is suggested that the Middle Archaic area of site 41 BX 305 be avoided during park development, and be left in a natural, unaltered state. Preservation of the site would be preferable; however, if this is not possible, we strongly urge the course of investigation recommended above. 


\section{ACKNOWLEDGMENTS}

Despite unusually hot weather, ravenous chiggers and mosquitoes, and the sighting of several rattlesnakes, the crew members put in many days of hard work in this excavation, and I am grateful to them. Crew members were: Carolyn Furman, Steve James, Paul Katz, Paul Lukowski, Jane Meyers, June Secrist and Tom Taylor.

The artifacts were cleaned and labeled by Elizabeth Frkuska; the Office of Instructional Services at The University of Texas at San Antonio prepared the maps and photographs. The manuscript was edited and typed by staff members of the UTSA Center for Archaeological Research, Dr. Thomas R. Hester, Director.

REFERENCES CITED

Frkuska, Elizabeth C., Augustine Frkuska, Fred Valdez, Jr. and Thomas R. Hester

1977 An Initial Archaeological Assessment of John James Park, City of San Antonio, Texas. Center for Archaeological Research, The University of Texas at San Antonio, Archaeological Survey Report 25.

Hester, Thomas R.

1975 A Chronological Overview of Prehistoric Southern and SouthCentral Texas. Paper presented at the Conference, "The Prehistory of Northeastern Mexico and Texas," Monterrey, Mexico, April 23-26, 1975.

Schuetz, Mardith K.

1966 The Granberg Site: An Archaic Indian Habitation in Bexar County, Texas. Witte Museum Studies. San Antonio.

Weir, Frank

1976 The Central Texas Archaic Reconsidered. In Hester, Thomas R., (ed.). The Texas Archaic: A Symposium. Center for Archaeological Research, The University of Texas at San Antonio, Special Report 2 . 
DISCUSSION OF THE RADIOCARBON DATE FROM 41 BX 305,

JOHN JAMES PARK

Since this report was printed, a radiocarbon date (see page 8 ) has been obtained. A sample of wood charcoal (TX-2805), submitted to the Radiocarbon Laboratory at The University of Texas at Austin, has been dated at A.D. 720 (1230 \pm 50 B.P.). This sample, recovered from Unit $\mathrm{C}-3$ at a depth of $40-50 \mathrm{~cm}$, was considered to be free of contaminants by the excavator. The date, therefore, should accurately reflect the age of the specimen and the feature with which it was associated. By extrapolation, the date should relate to the entire occupation of the site identified in various units at a consistent depth of $40 \mathrm{~cm}$ below the present ground surface.

As discussed in the body of the report, the diagnostic artifacts indicate that the site was occupied during the Middle and Middle-Late Archaic, the age of which has been estimated elsewhere as between 2250 B.C. - A.D. 150 (Weir 1976). The dates on which this temporal range is based are, unfortunately, derived from the lower Pecos River area of southwest Texas. Recent unpublished radiocarbon dates from other sites in south-central Texas suggest, however, that occupations comparable to that identified at 41 BX 305 in John James Park seem to be consistently dated later in time than their presumed counterparts to the north in Central Texas. Some of these dates include those reported by Hester from the La Jita site in Uvalde County (Bulletin, Texas Archeological Society, Vol. 42, 1971) and several dates from site 41 BX 228 and sites on Camp Bul7is, in northern Bexar County. The latter dates will be appearing in future Center publications.

Investigations at 41 BX 305 in John James Park, and at other sites in southcentral Texas, have demonstrated the validity of the relative cultural sequence currently employed for the Archaic period, while at the same time pointing to the need for establishing region-specific absolute chronologies rather than uncritically employing ones developed outside the region.

ERRATA: John James Park Report

Page 5, line 20 - "occurred" rather than "ocurred"

Page 6, line 19 - semicolon should follow "mixed"

Page 6, paragraph 3 - references to Figure 2,b and Figure $3, d$ should appear in this paragraph

Page 6, line 33 - "of" rather than "or"

Page 7 , caption - read "b," before "Feature 1."

Page 11 , line 26 - should read, "It is expected that a date..." 